\title{
ANALISIS PENERAPAN CORPORATE GOVERNANCE, KUALITAS AUDIT DAN PENGUNGKAPAN CSR SERTA UKURAN PERUSAHAAN TERHADAP INTEGRITAS LAPORAN KEUANGAN
}

\author{
Ranti Nugraheni \\ Universitas Pembangunan Nasional (UPN) Veteran Jakarta, Indonesia \\ Email: ranti.nugraheni@upnvj.ac.id
}

\begin{abstract}
Abstrak
Informasi yang disajikan pada laporan keuangan (LK) diharapkan memiliki nilai integritas yang tinggi. Untuk menyajikan LK yang berintegritas dipengaruhi oleh banyak faktor baik dari eksternal maupun internal perusahaan. Tujuan dari penelitian ini untuk mengetahui pengaruh pengawasan internal (komite audit) dan pengawasan external (kepemilikan institusional dan kualitas audit external), pengungkapan corporate social responsibility (CRS), ukuran perusahaan terhadap integritas laporan keuangan. Sampel penelitian ini adalah perusahaan listed di BEI untuk sektor manufaktur selama 3 tahun dari tahun 2016 sampai dengan 2018 dengan metode purpose-based sampling dalam pengumpulan datanya. Jenis penelitian ini adalah kuantitatif dengan menggunakan data sekunder dan analisis data dilakukan dengan regresi berganda dengan SPSS 25 dalam pengolahan data. Hasil penelitian ini memberikan bukti empiris bahwa kepemilikan institusional, kualitas audit, dan pengungkapan CSR memiliki pengaruh positif dan signifikan terhadap integritas laporan keuangan. Sedangkan ukuran perusahaan dan komite audit tidak berpengaruh signifikan pada integritas LK.
\end{abstract}

Kata Kunci: integritas laporan keuangan; kualitas audit; CSR; kepemilikan institusional; komite audit; ukuran perusahaan

\section{Abstract}

The information presented in the financial statements $(L K)$ is expected to have a high integrity value. To present financial statements with integrity, it is influenced by many factors, both external and internal to the company. The purpose of this study was to determine the effect of internal control (audit committee) and external supervision (institutional ownership and external audit quality), disclosure of corporate social responsibility (CRS), firm size on the integrity of financial statements. The sample of this research is companies listed on the Stock Exchange for the manufacturing sector for 3 years from 2016 to 2018 with a purpose-based sampling method in data collection. This type of research is quantitative using secondary data and data analysis is carried out by multiple regression with SPSS 25 in data processing. The results of this study provide empirical evidence that institutional ownership, audit quality, and CSR disclosure have a positive and significant effect on the integrity of financial statements. While the size of the company and the audit committee have no significant effect on the integrity of the financial statements.

$\begin{array}{ll}\text { How to cite: } & \text { Nugraheni, R., (2021) Analisis Penerapan Corporate Governance, Kualitas Audit dan Pengungkapan CSR } \\ & \text { Serta Ukuran Perusahaan terhadap Integritas Laporan Keuangan. Syntax Idea, } \\ & \text { https://doi.org/10.36418/syntax-idea.v3i9.1434 } \\ \text { E-ISSN: } & 2684-883 X \\ \text { Published by: } & \text { Ridwan Institute }\end{array}$


Keywords: integrity of financial statements; audit quality; CSR; institutional ownership; audit committee; company size

Received: 2021-08-22; Accepted: 2021-09-05; Published: 2021-09-20

\section{Pendahuluan}

Informasi dari Laporan keuangan (LK) adalah salah satu informasi hasil kinerja keuangan pada perusahaan yang dijadikan media komunikasi antara pengelola manajemen perusahaan sebagai pihak internal kepada pihak eksternal seperti investor. Untuk itu, pihak eksternal selalu mengharapkan pada laporan keuangan perusahaan yang dikeluarkan pihak manajemen adalah informasi keuangan yang jujur serta dapat dipercaya dalam mengungkapkan kinerja perusahaan. Pelaporan keuangan yang disajikan secara jujur dan tidak terdapat bias dalam pelaporannya akan memiliki nilai integritas yang tinggi (Indrasari et al., 2017). Namun pada kenyataannya, banyak perusahaan yang sering melaporkan kinerja perusahaan dengan ketidakjujuran didalam LK perusahaan yang disajikan oleh pihak manajemen.

Terdapat beberapa contoh ketidakjujuran dalam laporan keuangan dapat dilihat pada kasus yang terjadi di PT. Garuda Indonesia Tbk, PT. Tiga Pilar Sejahtera Food Tbk, dan PT. Asuransi Jiwasraya (Persero). Kasus PT. Tiga Pilar Sejahtera yang terjadi dalam laporan keuangan tahun 2017 terdapat overstatement senilai 4 triliun rupiah pada pos persediaan, piutang usaha, dan asset tetap. Kemudian pada kasus PT. Garuda Indonesia Tbk yang terungkap pada awal tahun 2019. Pada bulan April 2019, PT. Garuda Indonesia menerbitkan laporan keuangan kinerja tahun 2018 dan menyatakan bahwa perusahaan memiliki laba sekitar US\$809ribu, padahal sebelumnya pada tahun 2017 perusahaan ini mengalami kerugian sekitar US\$216,58juta. Hal ini cukup mencurigakan apabila melihat pada keadaan di kuartal III tahun 2018 perusahaan ini masih melaporkan mengalami kerugian sebesar US\$114,08juta. Setelah diselidiki lebih lanjut oleh berbagai pihak, diketahui bahwa permasalahan muncul karena PT. Garuda Indonesia mencatat piutang PT. Mahata Aero Teknologi sebagai pendapatan pada laporan keuangan perusahaan tahun 2018. Lalu untuk kasus PT. Jiwasraya mulai terungkap pada tahun 2018 karena perusahaan mengalami gagal bayar salah satu produk asuransi yang sebelumnya telah dikeluarkan oleh perusahaan. Setelah diselidiki oleh BPK, ditemukan fakta bahwa perusahaan sudah melakukan usaha pencatatan laba semu sejak tahun 2006.

Berdasarkan beberapa contoh kasus diatas maka dapat dilihat bahwa manajemen perusahaan yang membuat laporan keuangan dengan tidak jujur akan memiliki laporan keuangan bernilai integritas yang rendah. Sebab laporan keuangan yang dihasilkan tidak dapat dipercaya dan dapat merugikan pihak-pihak lain seperti pemegang saham, kreditur dan konsumen. Sehingga akan sangat penting bagi perusahaan untuk meningkatkan integritas laporan keuangan. Integritas laporan keuangan sendiri dapat diartikan sebagai suatu kondisi dimana menampilkan kondisi informasi keuangan yang sebenarnya. Laporan keuangan yang berintegritas sangat penting karena 
mengambarkan nilai perusahaan yang sebenarnya, dan meningkatkan kepercayaan pihak investor dan stakeholder lainnya yang merupakan sinyal positif bagi pengguna informasi LK (Parinduri, et al., 2019).

Adanya ketidakjujuran dalam pembuatan laporan keuangan biasanya disebabkan karena pihak manajemen ingin kepentingannya terpenuhi dengan memberikan kompensasi yang memadai atas usaha yang dikelolanya dalam perusahaan. Di sisi lain, pemegang saham ingin memprioritaskan pengembalian finansial atas investasi yang mereka investasikan di perusahaan. Dari perbedaan tersebut timbul konflik kepentingan dalam hubungan keagenan. Hal ini searah dengan teori keagenan, dimana mengasumsikan setiap tindakan diambil dengan dasar memprioritaskan kepentingan masing-masing baik agen (manajemen) maupun principal (pemegang saham).

Agar dapat menyajikan LK yang berintegritas terdapat banyak faktor yang akan dapat mempengaruhi perusahaan. Salah satu faktornya yaitu adanya tata kelola yang baik di perusahaan atau good corporate governance (GCG). Dengan diterapkannya secara baik sistem tata kelola perusahaan yang sesuai, maka diharapkan bisa meminimalisir terjadinya kecurangan dalam pelaporan kinerja perusahaan. Sebab diharapkan sistem ini dapat mengatur hubungan antara dewan komisaris, dewan direksi, serta pemegang saham untuk mencegah terjadinya beberapa kesalahan yang mungkin terjadi dan diharapkan dapat segera diperbaiki (Mais \& Nuari, 2016).

Penelitian sebelumnya tentang pengaruh penerapan $G C G$ terhadap integritas LK telah dilakukan. Diantaranya penelitian (Parinduri et al., 2019) dan (Sauqi et al., 2017). Para peneliti tersebut telah melakukan penelitian mengenai adanya pengaruh variabel kepemilikan institusional dan variabel komite audit pada LK yang berintegritas dengan jenis sampel yang berbeda-beda dengan rentang waktu yang juga berbeda. (Parinduri et al., 2019) telah melakukan penelitian dengan menggunakan sampel perusahaan LQ45 pada periode 2015-2017, kemudian (Sauqi et al., 2017) telah melakukan penelitian dengan digunakan sampel perusahaan manufaktur untuk periode 2012-2015. Hasil penelitian yang mereka peroleh menyatakan kesimpulan yang sama, yaitu kepemilikan institusional berpengaruh positif pada LK yang berintegritas, namun komite audit tidak terbukti berpengaruh signifikan. Namun hasil yang berbeda diperoleh berdasarkan penelitian oleh (Mais \& Nuari, 2016) dan (Priharta, 2017) yang telah menyimpulkan bahwa terdapat pengaruh negative antara kepemilikan institusional dan integritas LK. Sementara penelitian sebelumnya yaitu (Nurdiniah dan Pradika, 2017) memberikan bukti empiris yang menemukan bahwa variabel kepemilikan institusional mempunyai pengaruh yang tidak signifikan. Begitu juga dengan penelitian yang sebelumnya telah dilakukan oleh (Hasanuddin, 2018) dengan menggunakan sampel perusahaan manufaktur. Penelitian (Hasanuddin, 2018) menghasilkan bukti empiris tidak terdapat pengaruh antara kepemilikan institusional dengan integritas LK, akan tetapi untuk komite audit pada hasil penelitian ini terbukti memberikan pengaruh positif pada integritas LK.

Selain penerapan GCG, kualitas audit juga diduga memiliki dampak pada integritas laporan keuangan. Kualitas audit sendiri merupakan proses pemeriksaan 
sistematis terhadap sistem baik yang dilakukan oleh internal dan eksternal auditor pada suatu organisasi. Menurut (Priharta, 2017), kualitas audit atas laporan keuangan memberikan dampak terhadap peningkatan kepatuhan pada penerapan standar akuntansi keuangan yang disertai dengan peningkatan transparansi laporan keuangan yang akan disajikan. Hal ini berarti kualitas audit juga termasuk salah satu faktor yang mungkin dapat meningkatkan nilai integritas LK. Penelitian terdahulu tentang pengaruh kualitas audit terhadap peningkatan nilai integritas LK telah dilakukan oleh (Priharta, 2017). Penelitian tersebut telah memberikan hasil bahwa kualitas audit ada pengaruhnya secara positif terhadap integritas LK. Sementara hasil penelitian sebelumnya oleh (Serly dan Helmayunita, 2019) menemukan bahwa kualitas audit tidak berpengaruh pada integritas LK.

Selain penerapan GCG dan kualitas audit, CSR juga diduga bisa memberikan pengaruh pada nilai integritas laporan keuangan. Kegiatan CSR merupakan tanggung jawab sosial perusahaan dimana ini merupakan kewajiban yang dimiliki perusahaan terhadap pihak yang berkepentingan termasuk masyarakat serta lingkungan eksternal sebagai akibat dari kegiatan operasional perusahaan. Menurut (Santi \& Wardani, 2018), perusahaan atau entitas yang melakukan kegiatan CSR serta mengungkapkan kegiatan CSR tersebut dalam laporan keuangan mereka, maka akan mendapatkan manfaat yaitu peningkatan citra yang positif dari investor dan masyarakat. Hal ini disebabkan oleh perusahaan yang punya CSR serta berkomitmen dalam melaksanakan kebijakan CSR yang telah dimilikinya akan mendorong pihak manajemen untuk meningkatkan kinerja operasi perusahaan dan diharapkan akan mengurangi tindakan-tindakan yang tidak etis dalam melakukan manajemen laba. Dengan berkurangnya tindakan tidak etis dalam praktik manajemen laba, maka akan meningkatkan transparansi dan nilai kejujuran dalam pelaporan kinerja keuangan, sehingga hal ini akan meningkatkan nilai integritas LK. Menurut penelitian terdahulu yaitu (Cho et al., 2020) diperoleh hasil bahwa manajer perusahaan menggunakan pengungkapan CSR untuk menyampaikan informasi yang lebih kredibel ke pasar yang pada gilirannya dikaitkan dengan reaksi pasar yang kuat terhadap pengungkapan CSR. Hal ini mengambarkan bahwa terdapat indikasi jika CSR memiliki pengaruh positif pada peningkatan nilai integritas laporan keuangan. Namun penelitian (Cho et al., 2020) ini hanya melihat pengaruh CSR terhadap derajat konservatisme akuntansi saja, dimana konservatisme merupakan salah satu pengukuran untuk integritas laporan keuangan. Pengaruh variabel lain seperti implementasi GCG serta kualitas audit tidak diteliti pada penelitiannya. Selain itu, jenis sampel perusahaan pada penelitian tersebut menggunakan sampel perusahaan di negara lain.

Selanjutnya, besarnya perusahaan diduga menjadi salah satu faktor yang mempengaruhi manajemen dalam menyusun LK. Menurut (Nurdiniah \& Pradika, 2017) perusahaan dengan skala besar akan dihadapkan pada tuntutan stakeholders yang lebih besar pula dalam menyusun LK sesuai dengan kondisi keuangan sebenarnya dibandingkan dengan perusahaan kecil. Walaupun skandal kecurangan yang terjadi lebih sering melibatkan perusahaan berskala besar, namun karena perusahaan ini mendapat perhatian lebih dari berbagai pihak, maka perusahaan besar akan 
menyediakan informasi berupa laporan keuangan dengan penuh kehati-hatian. Penelitian yang sudah pernah dikerjakan oleh (Nurdiniah \& Pradika, 2017) menghasilkan kesimpulan bahwa ukuran perusahaan yang lebih besar akan meningkatkan integritas LK, sebaliknya hasil penelitian (Parinduri et al., 2019) dan (Wardhani \& Samrotun, 2020) menyimpulkan bahwa besarnya perusahaan tidak mempengaruhi integritas LK perusahaan.

Dari penjabaran yang telah dibahas di atas, bisa dilihat bahwa para peneliti lebih banyak melakukan penelitian tentang pengaruh penerapan $G C G$ pada integritas LK, seperti yang sudah dilakukan pada penelitian (Parinduri et al., 2019), (Sauqi et al., 2017), (Mais \& Nuari, 2016), (Priharta, 2017), (Nurdiniah \& Pradika, 2017), serta (Hasanuddin, 2018) meskipun mereka memperoleh hasil yang berbeda-beda dalam penelitiannya. Sementara penelitian mengenai pengaruh pengungkapan CSR pada integritas LK sangat jarang dilakukan, sedangkan pengungkapan CSR merupakan suatu hal yang penting karena memberikan indikasi bahwa perusahaan memiliki CSR kepada masyarakat. Melalui pengungkapan CSR, penilaian investor bahwa perusahaan memiliki kinerja operasional yang baik sehingga diharapkan dapat meningkatkan nilai integritas laporan keuangan karena manajer tidak perlu melakukan manajemen laba secara masif. Oleh karena itu, peneliti menduga bahwa jika penerapan good corporate governance digabungkan bersama dengan adanya pengungkapan CSR serta kualitas audit yang baik maka akan meningkatkan nilai integritas LK. Selain itu, apabila ketiga komponen diatas dilakukan oleh perusahaan berskala besar, tentu diharapkan nilai integritas laporan keuangan juga akan semakin baik.

Dengan menggunakan alasan yang telah dikemukakan tersebut di atas, maka untuk penelitian ini, peneliti akan melakukan penelitian tentang pengaruh penerapan $G C G$, kualitas audit, pengungkapan CSR dan ukuran perusahaan terhadap integritas LK. Dimana pengembangan hipotesis untuk penelitian ini yaitu sebagai berikut:

$\mathrm{H}_{1}$ : Terdapat pengaruh antara Kepemilikan institusional dan integritas LK

$\mathrm{H}_{2}$ : Terdapat pengaruh antara Komite audit dan integritas LK.

$\mathrm{H}_{3}$ : Terdapat pengaruh antara Kualitas audit dan integritas LK.

$\mathrm{H}_{4}$ : Terdapat pengaruh antara Pengungkapan CSR dan integritas LK.

$\mathrm{H}_{5}$ : Terdapat pengaruh antara Ukuran perusahaan dan integritas LK.

\section{Metode Penelitian}

Penelitian ini adalah jenis penelitian kuantitatif dengan populasi data perusahaan pada industri manufaktur yang telah terdaftar pada Bursa Efek Indonesia (BEI). Dari seluruh perusahaan yang terdaftar, tidak semua perusahaan diambil sebagai sampel. Hanya diambil sebagian perusahaan yang memenuhi beberapa kriteria tertentu pada periode 2016-2018, perusahaan menyajikan pengungkapan CSR yang disertakan pada laporan tahunannya dan memiliki LK yang lengkap, dan melalui proses audit serta tidak terhapus dari daftar bursa pada tahun pengamatan. Data yang digunakan dalam penelitian ini yaitu berupa data sekunder, dimana data diperoleh dari laporan tahunan yang dipublikasikan melalui situs web www.idx.co.id. 


\section{Integritas Laporan Keuangan}

Pengukuran variabel terikat yaitu integritas laporan keuangan akan mengacu pada penelitian (Wardhani \& Samrotun, 2020) diukur dengan index conservatism, sebagai berikut :

Keterangan:

$$
\mathrm{ILK}_{\mathrm{it}}=\text { Harga Pasar persaham / Nilai Buku persaham }
$$

ILK $\quad=$ Integritas Laporan Keuangan Perusahan i pada tahun ke-t

Harga pasar persaham = Harga pasar saham saat penutupan harga akhir.

Nilai buku persaham = Jumlah ekuitas dibagi jumlah saham yang beredar.

Index conservatism menurut (Beaver \& Ryan, 2000) menyatakan bahwa kecenderungan nilai buku lebih rendah dibandingkan nilai pasar. Apabila rasio nilai menunjukan lebih dari 1 mengindikasikan terdapat penerapan konservatisme disebabkan pencatatan rendahnya nilai buku dari pada nilai pasar oleh perusahaan. Nilai rasio dari harga pasar saham dibandingkan nilai buku menggambarkan tanggapan pemegang saham terhadap entitas, artinya pemegang saham akan membayar saham lebih tinggi dari nilai buku. Bila perusahaan memiliki harga pasar saham yang lebih tinggi akan mencerminkan laporan keuangan yang baik. Kriteria untuk mengetahui integritas laporan keuangan adalah:

a. ILK $<1$, berarti integritas LK pada entitas tersebut masih rendah.

b. ILK > 1, berarti integritas LK pada entitas tersebut baik karena nilainya lebih besar dari satu.

\section{Kepemilikan Institusional}

Pengukuran kepemilikan institusional pada penelitian akan menggunakan skala rasio seperti yang digunakan oleh (Parinduri et al., 2019). Persamaan yang digunakan yaitu dengan memperbandingkan jumlah saham institusi di entitas dengan saham milik entitas yang beredar. Berikut dapat dirumuskan dibawah ini:

$\mathrm{KI}=($ Jumlah saham yang dimiliki institusional / Jumlah saham yang beredar $) \mathrm{X}$ $100 \%$

\section{Komite Audit}

Pengukuran komite audit mengacu dari pengukuran (Sultana et al., 2015) yaitu diukur dari pengalaman komite audit sebelumnya di perusahaan. Pengukuran menggunakan variabel dummy, apabila minimal 1 anggota komite audit perusahaan i pada periode waktu t telah memiliki pengalaman sebagai komite audit sebelumnya maka diberi nilai 1, dan apabila tidak memiliki pengalaman maka akan diberikan nilai 0 . Apabila minimal 1 anggota komite audit memiliki pengalaman sebelumnya, akan lebih memiliki pemahaman efektif atas tanggungjawabnya.

\section{Kualitas Audit}

Kualitas audit mengacu dari pengukuran (Abdillah et al., 2019) yaitu mengukur kualitas audit dengan digunakan proksi spesialisasi auditor sebagai variabel dummy. Bila auditor termasuk dalam golongan berspesialisasi industri maka diberikan nilai 1, dan bila auditor merupakan nonspesialisasi industry maka diberikan nilai 0. Penelitian 
ini menggunakan pengukuran dengan pendekatan nilai pasar. Dapat dirumuskan sebagai berikut ini:

Kualitas Audit $=($ Jumlah Klien KAP dalam industri/Jumlah Seluruh Emiten dalam Industri) X (Rerata Aset Klien KAP dalam Industri / Rerata Aset Seluruh Emiten dalam Industri)

KAP dikatakan memiliki spesialisasi industri auditor jika KAP menguasai $10 \%$ market share, namun jika menguasai kurang dari $10 \%$ market share itu berarti KAP belum memiliki spesialisasi industri (Setiawan \& Fitriany, 2011).

Corporate Social Responsibility

Dalam mengukur pengungkapan CSR, digunakan indikator pengungkapan yang telah dipublikasikan oleh Global Reporting Initiative (GRI) yang berbentuk tabel checklist. Digunakan GRI versi 4 untuk penelitian ini, dimana terdapat total 91 item yang diharapkan diungkapkan oleh perusahaan. Rumus yang akan digunakan untuk menghitung CSRI yaitu:

Keterangan:

$$
\operatorname{CSRIj}=\frac{\sum X i j}{n j}
$$

CSRIj = CSR Disclosure Index perusahaan j.

$\mathrm{Xij} \quad=0$ jika item i tidak diungkapkan; nilai 1 jika item i diungkapkan.

nj $\quad=$ total jumlah item untuk perusahaan $\mathrm{j}$.

\section{Ukuran Perusahaan}

Ukuran perusahaan dapat merefleksikan kondisi besar atau kecilnya suatu entitas usaha dengan indikator tertentu. Salah indikator yang mampu merepresentasikan skala ukuran perusahaan adalah banyaknya aset yang dimiliki. Menurut (Wardhani \& Samrotun, 2020) untuk menilai ukuran dari entitas usaha dapat menggunakan perhitungan logaritma natural pada nilai buku total aset entitas usaha yang tersaji dalam persamaan berikut ini:

$$
\text { Ukuran perusahaan }=\text { Ln }(\text { Total Asset })
$$

Digunakan analisis regresi linier berganda untuk metode analisis data pada penelitian, dan pengolahan data digunakan bantuan perangkat lunak statistik SPSS 25. Pada penelitian digunakan model regresi linier berganda berikut ini:

$$
\text { ILK }=\alpha+\beta_{1} \mathrm{CSR}+\beta_{2} \mathrm{KI}+\beta_{3} \text { KomAudit }+\beta_{4} \text { KualAudit }+\beta_{5} \text { Ukuran }+\mathrm{e}
$$

Keterangan:

$\begin{array}{ll}\text { ILK } & =\text { Integritas LK } \\ \alpha & =\text { konstanta } \\ \beta_{1}-\beta_{5} & =\text { Koefisien Regresi } \\ \text { CSR } & =\text { Corporate Social Responsibility } \\ \text { KI } & =\text { Kepemilikan Institusional } \\ \text { KomAudit } & =\text { Komite Audit } \\ \text { KualAudit } & =\text { Kualitas Audit }\end{array}$


$\begin{array}{ll}\text { Ukuran } & =\text { Ukuran Perusahaan } \\ \mathrm{e} & =\text { error } \text { atau kesalahan residual }\end{array}$

\section{Hasil dan Pembahasan}

Pengolahan data awal diperoleh hasil pengujian statistik deskriptif untuk variabelvariabel yang digunakan pada penelitian ini yaitu sebagai berikut seperti yang tersaji pada Tabel 1.

Tabel 1

Stat. Deskriptif

\begin{tabular}{lcrrr}
\hline & N & \multicolumn{1}{c}{ Min } & \multicolumn{1}{c}{ Max } & \multicolumn{1}{c}{ Mean \pm Std. Dev. } \\
\hline ILK & 114 & -1.22041 & 5.3669 & $1.4274 \pm 1.26492$ \\
\hline CSR & 114 & 0.010989 & 0.10989 & $0.0317139 \pm 0.018128$ \\
\hline KI & 114 & 0.05143 & 0.99586 & $0.7230457 \pm 0.20189384$ \\
\hline KomAudit & 114 & 0 & 1 & $0.63 \pm 0.485$ \\
\hline KualAudit & 114 & 0 & 1 & $0.31 \pm 0.463$ \\
\hline Ukuran & 114 & 24.177 & 33.4737 & $28.41786 \pm 1.85094$ \\
\hline
\end{tabular}

Sumber: Data diolah SPSS 25 tahun 2021

Dari data yang telah disajikan pada Tabel 1 di atas, dapat dilihat bahwa variabel integritas laporan keuangan (ILK) memiliki nilai minimum sebesar -1.22041 yang dimiliki oleh perusahaan berkode saham BIMA (Primarindo Asia Infrastructure Tbk.), dan nilai maksimum sebesar 5.3669 dimiliki oleh perusahaan berkode saham ICBP (Indofood CBP Sukses Makmur Tbk.). Nilai ILK yang tinggi yang dimiliki oleh ICBP menunjukkan bahwa masyarakat menilai perusahaan memiliki integritas laporan keuangan yang baik dimata masyarakat dan investor sehingga mereka mau menginvesatasikan uang mereka di ICBP meskipun harga pasar persaham perusahaan ini bernilai 5,3 kali lipat lebih tinggi dari nilai bukunya. Selain itu, nilai standar deviasi yang dimiliki variabel ILK juga cukup rendah meskipun tidak mendekati angka nol. Ini berarti nilai ILK cukup bervariasi meskipun variasinya tidak cukup besar. Dari data yang ditampilkan oleh Tabel 1 juga dapat dilihat bahwa variabel pengungkapan corporate social responsibility (CSR) memiliki nilai terendah 0.010989 serta nilai tertinggi sebesar 0.10989. Nilai terendah tersebut dimiliki oleh perusahaan berkode saham BIMA (Primarindo Asia Infrastructure Tbk.) dan BOLT (Garuda Metalindo Tbk.). Kedua perusahaan tersebut selama 3 tahun berturut-turut hanya mampu mengungkapkan 1 item dari total 91 item komponen CSR yang dapat diungkapkan menurut indikator GRI. Untuk nilai CSR tertinggi dimiliki oleh perusahaan berkode saham INAF (Indofarma Tbk.) dimana perusahaan ini mampu secara konsisten selama 3 tahun berturut-turut mengungkapkan 10 item dari total 91 item komponen CSR. Selain itu, nilai standar deviasi yang dimiliki variabel CSR sangat rendah, yaitu sebesar 0.018128 yang nilainya hampir mendekati angka nol. Ini berarti nilai CSR tidak banyak bervariasi bahkan nilainya cenderung mendekati nilai rata-rata. Kemudian untuk variabel kepemilikan institusional berdasarkan data pada Tabel 1 memiliki nilai maksimal sebesar 0.99586 dimiliki oleh perusahaan IMPC (Impact Pratama Industri 
Tbk.) dan nilai minimal sebesar 0.05143 dimiliki oleh perusahaan WIIM (Wismilak Inti Makmur Tbk.). Nilai kepemilikan institusional yang tinggi pada perusahaan IMPC menunjukkan bahwa hampir keseluruhan saham perusahaan ini dimiliki oleh institusi lain. Untuk variabel ukuran perusahaan memiliki nilai terendah sebesar 24.177 milik perusahaan berkode saham ICBP (Indofood CBP Sukses Makmur Tbk.) dan nilai tertinggi sebesar 33.4737 yang dimiliki oleh perusahaan berkode saham ASII (Astra International Tbk.). Ukuran perusahaan tertinggi dimiliki oleh ASII merupakan suatu kewajaran mengingat perusahaan tersebut telah berdiri sejak lama dan masih terus beroperasi hingga saat ini dengan barang-barang yang cukup bervariasi dengan harga tinggi yang diproduksi oleh perusahaan ini. Selanjutnya untuk variabel komite audit (KomAudit) dan kualitas audit (KualAudit) memiliki nilai terendah senilai 0 dan nilai tertinggi sebesar 1 karena merupakan variable dummy. Berdasarkan nilai rata-rata untuk variabel komite audit pada Tabel 1 yaitu sebesar 0.63 . Hasil tersebut menunjukkan bahwa terdapat lebih dari $60 \%$ komite audit yang sedang menjabat pada perusahaanperusahaan sampel, mereka telah memiliki pengalaman sebagai komite audit sebelum menjabat pada posisi komite audit saat ini. Sementara berdasarkan nilai rata-rata untuk variabel kualitas audit pada Tabel 1 yaitu sebesar 0.31. Hal ini menunjukkan kurang dari $50 \%$ perusahaan yang dijadikan sampel menggunakan auditor yang sudah terspesialisasi untuk melakukan audit pada industri yang digunakan sebagai bahan penelitian.

Uji asumsi klasik yang pertama dilakukan penelitian ini yaitu uji normalitas, dimana untuk penelitian ini uji normalitas dihitung dengan menggunakan uji K-S (Kolmogorov-Smirnov). Hasil perhitungan pada Tabel 2 untuk uji normalitas dari residual model regresi, diperoleh probabilitas nilai signifikansi sebesar 0,056 yang bernilai lebih besar dari 5\%. Dengan adanya hasil ini maka dapat diperoleh kesimpulan bahwa residual data pada model regresi berganda memiliki distribusi data normal.

Tabel 2

\section{Hasil Uji Normalitas Residual}

\begin{tabular}{lr}
\hline Sig. (2-tailed) & $0.056^{\mathrm{c}}$ \\
\hline Test Statistic & 0.082 \\
\hline $\mathrm{N}$ & 114 \\
\hline \multicolumn{2}{l}{ Sumber: Data diolah SPSS 25 tahun 2021}
\end{tabular}

Untuk penelitian ini, pengujian asumsi heteroskedastisitas dilakukan dengan memakai grafik scatterplot. Hasil grafik plot dari studentized residual dan standardized predictive value dengan variabel terikat integritas laporan keuangan untuk uji heteroskedastisitas tersaji pada Gambar 1. Berdasarkan Gambar 1, grafik plot menyajikan gambar dimana titik-titik data yang terlihat menyebar dengan acak tanpa adanya pola tertentu pada daerah di sekitar area bawah dan di sekitar area atas angka 0 dari sumbu vertikal Y. Maka berdasarkan gambar plot yang tersaji dapat diambil kesimpulan bahwa untuk model regresi linear berganda yang digunakan dalam 
penelitian ini tidak menunjukkan adanya gejala terjadi heteroskedastisitas, dan oleh sebab itu model regresi bisa digunakan untuk analisis lebih lanjut pada penelitian.

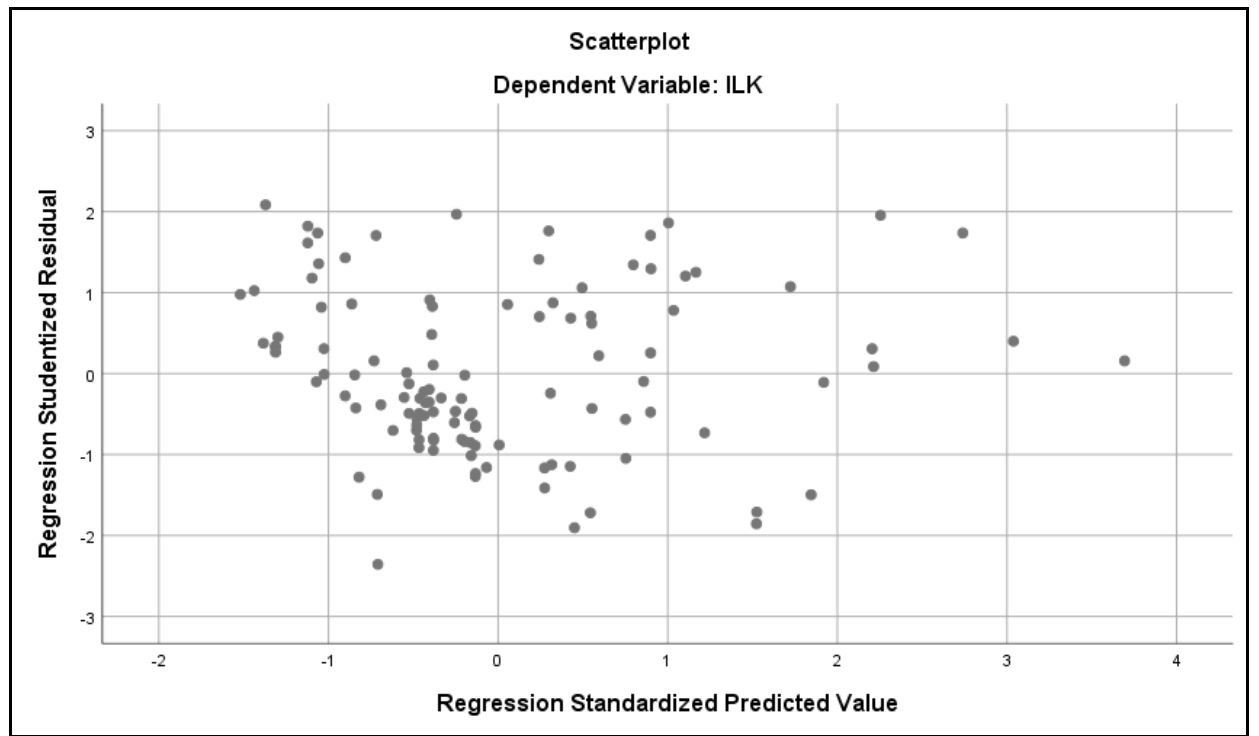

Gambar 1

Hasil Scatterplot Uji Heteroskedastisitas

Kemudian untuk uji multikolinearitas, dengan melihat nilai hasil tolerance dan variance inflation factor (VIF). Dengan melihat hasil berdasarkan Tabel 3 yang tersaji di bawah ini, dapat dilihat bahwa VIF untuk setiap variable-variabel bebas memiliki nilai kurang dari $10(<10)$ dan nilai tolerance lebih besar dari $0,1(>0,1)$. Dimana secara berturut-turut dapat dilihat bahwa nilai VIF untuk variabel CSR, Kepemilikan Institusional (KI), Komite Audit (KomAudit), Kualitas Audit (KualAudit), dan Ukuran perusahaan memiliki nilai 1.134, 1.052, 1.092, 1.204, dan 1.196. Sedangkan nilai tolerance untuk variabel CSR, Kepemilikan Institusional (KI), Komite Audit (KomAudit), Kualitas Audit (KualAudit), dan Ukuran perusahaan memiliki nilai 0.882, 0.950, 0.916, 0.831, dan 0.836. Sehingga bisa diambil kesimpulan bahwa tidak terlihat adanya gejala multikolinearitas antar variabel bebas yang digunakan pada model regresi ini.

\begin{tabular}{|c|c|c|}
\hline \multicolumn{3}{|c|}{ Tabel 3. Hasil Uji Multikolinearitas } \\
\hline \multirow{2}{*}{ Model } & \multicolumn{2}{|c|}{ Collinearity Stat. } \\
\hline & Tolerance & VIF \\
\hline 1 & & \\
\hline CSR & 0.882 & 1.134 \\
\hline KI & 0.950 & 1.052 \\
\hline KomAudit & 0.916 & 1.092 \\
\hline KualAudit & 0.831 & 1.204 \\
\hline Ukuran & 0.836 & 1.196 \\
\hline
\end{tabular}

Sumber: Data diolah SPSS 25 tahun 2021 
Selanjutnya untuk uji autokorelasi model regresi penelitian, dilakukan dengan cara melihat nilai Durbin-Watson (DW). Berdasarkan Tabel 4 yang tersaji di bawah, bisa dilihat bahwa model memiliki nilai DW sebesar 2,201 dan kemudian nilai ini akan diperbandingkan dengan nilai pada tabel DW dengan N sebanyak 114 dan K sebesar 6 karena total variabel bebas dan variabel terikat yang dipakai untuk diolah pada penelitian yaitu sebanyak 6 variabel. Setelah melihat pada tabel Durbin-Watson didapatkan nilai dU sebesar 1,78691 dan nilai dL sebesar 1,60421. Nilai DW model pada Tabel 4 sebesar 2,201, nilai ini lebih besar dari batas atas (dU) yaitu 1,78691 dan lebih kecil dari (4- dU), 4-1,78691 = 2,21309 sehingga bisa diambil kesimpulan bahwa pada model regresi penelitian tidak ada autokorelasi.

\section{Tabel 4}

Koefisien Determinasi dan Hasil Uji Autokorelasi

\begin{tabular}{lcrrrr}
\hline Model & $\mathrm{R}$ & $\begin{array}{r}\mathrm{R} \\
\text { Square }\end{array}$ & $\begin{array}{c}\text { Adjusted } \\
\text { R Square }\end{array}$ & $\begin{array}{c}\text { Std. Error of } \\
\text { the Estimate }\end{array}$ & $\begin{array}{c}\text { Durbin- } \\
\text { Watson }\end{array}$ \\
\hline 1 & $0.740^{\mathrm{a}}$ & 0.547 & 0.526 & 0.87050395 & 2.201 \\
\hline \multicolumn{7}{l}{ Sumber: Data diolah SPSS } & 25 tahun 2021
\end{tabular}

Hasil uji koefisien determinasi penelitian dapat dilihat berdasarkan hasil yang disajikan oleh Tabel 4, bisa dilihat dari Tabel 4 nilai koefisien determinasi $\left(\mathrm{R}^{2}\right)$ sebesar 0.547. Hal ini menunjukkan bahwa variable-variabel bebas yang dimiliki yaitu kepemilikan institusional, komite audit, corporate social responsibility, kualitas audit, dan ukuran perusahaan mempengaruhi integritas laporan keuangan sebesar 54,7\%. Sedangkan 45,3\% variabel integritas laporan keuangan dipengaruhi oleh variabelvariabel lain yang tidak disertakan pada model penelitian yang ada seperti komisaris independen, kepemilikan manajerial, dan kualitas KAP.

\section{Tabel 5}

\section{Hasil Uji Simultan}

\begin{tabular}{|c|c|c|c|c|c|}
\hline Model & $\begin{array}{l}\text { Sum of } \\
\text { Squares }\end{array}$ & df & $\begin{array}{l}\text { Mean } \\
\text { Square }\end{array}$ & $\mathrm{F}$ & Sig. \\
\hline 1 Regression & 98.963 & 5 & 19.793 & 26.119 & $0.000^{b}$ \\
\hline Residual & 81.840 & 108 & 0.758 & & \\
\hline Total & 180.803 & 113 & & & \\
\hline
\end{tabular}

Hasil uji $\mathrm{F}$ adalah mengambarkan hasil uji pengaruh simultan dari variabel bebas terhadap variabel terikat $\mathrm{F}$, dapat dilihat pada hasil yang tersaji di Tabel 5. Dari data yang tersaji di Tabel 5, diperoleh nilai $\mathrm{F}$ sebesar 26,119 dan probabilitas signifikansi sebesar 0,000, nilai ini lebih kecil dari tingkat kesalahan $\alpha$ senilai 5\%. Sehingga bisa diambil kesimpulan yaitu variabel-variabel bebas pada model yaitu kepemilikan institusional, komite audit, corporate social responsibility, kualitas audit, dan ukuran perusahaan secara simultan mempengaruhi integritas laporan keuangan. 
Selanjutnya dari hasil pengolahan data yang disajikan pada Tabel 6, dapat diperoleh model persamaan regresi linear berganda pada penelitian yaitu sebagai berikut:

$\mathrm{ILK}=-0.680+41.444 \mathrm{CSR}+1.666 \mathrm{KI}+0.022 \mathrm{KomAudit}+0.653 \mathrm{Kual}$ Audit -

0.022 Ukuran

Tabel 6

Hasil Uji Parsial

\begin{tabular}{|c|c|c|c|c|c|c|}
\hline \multirow{2}{*}{\multicolumn{2}{|c|}{ Model }} & \multicolumn{2}{|c|}{$\begin{array}{c}\text { Unstandardized } \\
\text { Coef. }\end{array}$} & \multirow{2}{*}{$\begin{array}{c}\text { Standardiz } \\
\text { ed Coef. } \\
\text { Beta }\end{array}$} & \multirow[t]{2}{*}{$\mathbf{t}$} & \multirow[t]{2}{*}{ Sig. } \\
\hline & & B & Std. Error & & & \\
\hline \multirow[t]{6}{*}{1} & (Constant) & -0.680 & 1.333 & & -0.510 & 0.611 \\
\hline & CSR & 41.444 & 4.811 & 0.594 & 8.614 & 0.000 \\
\hline & $\mathrm{KI}$ & 1.666 & 0.416 & 0.266 & 4.005 & 0.000 \\
\hline & KomAudit & 0.022 & 0.177 & 0.008 & 0.125 & 0.901 \\
\hline & KualAudit & 0.653 & 0.194 & 0.239 & 3.368 & 0.001 \\
\hline & Ukuran & -0.022 & 0.048 & -0.032 & -0.456 & 0.649 \\
\hline
\end{tabular}

Sumber: Data diolah SPSS 25 tahun 2021

\section{Pengaruh Kepemilikan Institusional Terhadap Integritas Laporan Keuangan}

Hipotesis yang pertama untuk penelitian ini menyatakan bahwa kepemilikan institusional memiliki pengaruh terhadap integritas LK. Dengan melihat hasil pengujian yang telah disajikan pada Tabel 6, telah ditunjukkan bahwa kepemilikan institusional memiliki koefisien regresi sebesar 1,666. Nilai ini menunjukkan bahwa jika variabel kepemilikan institusional berubah sebesar satu satuan dan variabel lain dianggap konstan, maka variabel integritas laporan keuangan akan bertambah sebesar 1,666 satuan. Pada Tabel 6 untuk variabel kepemilikan institusional memiliki nilai probabilitas signifikansi senilai 0,000 yang lebih kecil dari tingkat kesalahan $\alpha$ senilai 5\%. Sehingga kepemilikan institusional dapat dikatakan mempunyai pengaruh signifikan dan positif pada integritas LK. Arah koefisien yang positif ini menunjukkan bahwa semakin besar nilai proporsi kepemilikan institusional pada suatu entitas, maka nilai integritas LK juga semakin tinggi.

Temuan dari hasil penelitian ini tidak mendukung hasil penelitian (Mais \& Nuari, 2016) dan (Priharta, 2017) yang menyimpulkan bahwa kepemilikan institusional memiliki pengaruh negatif dan signifikan pada integritas LK. Selain itu, temuan penelitian ini juga tidak searah dengan hasil dari peneliti terdahulu diantaranya (Nurdiniah \& Pradika, 2017) dan (Hasanuddin, 2018) yang menemukan bahwa kepemilikan institusional tidak berpengaruh pada integritas LK. Namun hasil dari penelitian ini mendukung hipotesis dan hasil ini juga didukung hasil penelitian yang sudah dilakukan oleh (Parinduri et al., 2019) serta (Sauqi et al., 2017) yang menyatakan jika kepemilikan institusional mempengaruhi secara positif pada integritas LK. Hal ini memberikan bukti secara empiris bahwa dengan diterapkannya secara baik sistem tata kelola perusahaan yang sesuai, maka bisa meminimalisir terjadinya kecurangan dalam pelaporan kinerja perusahaan. Sebab sistem tata kelola 
perusahaan yang baik ini dapat mengatur hubungan antara dewan komisaris, dewan direksi, serta pemegang saham untuk mencegah terjadinya beberapa kesalahan yang mungkin terjadi pada saat proses pembuatan laporan kinerja perusahaan dan diharapkan dapat segera diperbaiki. Apabila proses pembuatan laporan kinerja perusahaan berjalan dengan baik sesuai dengan aturan yang berlaku maka masyarakat dan investor akan menilai baik laporan keuangan perusahaan yang dihasilkan dan nilai integritas laporan keuangan perusahaan juga akan meningkat.

\section{Pengaruh Komite Audit Terhadap Integritas Laporan Keuangan}

Hipotesis yang kedua dari penelitian menyatakan bahwa komite audit memiliki pengaruh terhadap integritas LK. Hipotesis ini tidak terdukung dengan hasil olah data yang telah dilakukan. Hal ini terbukti dengan hasil pengujian yang disajikan pada Tabel 6 pada penelitian ini. Hasil pada Tabel 6 untuk variabel komite audit diperoleh nilai probabilitas signifikansi hitung sebesar 0,901 yang bernilai lebih besar dari tingkat kesalahan $\alpha$ yang diperbolehkan yaitu senilai 5\%. Ini artinya variabel komite audit tidak mempunyai pengaruh signifikan terhadap integritas LK. Hasil ini tidak mendukung hipotesis meskipun hasil pengujian menunjukkan komite audit memiliki koefisien positif yang cukup kecil yaitu sebesar 0,022. Hal ini mungkin terjadi karena peran komite audit kurang berfungsi secara maksimal sebagai penelaah dan pengawas pada proses pembuatan LK. Selain itu terdapat kemungkinan bahwa komite audit kurang bisa menjalankan perannya sebagai fasilitator dalam menjembatani komunikasi dalam hal yang berkaitan dengan audit pada dewan direksi.

Temuan penelitian ini tidak mendukung hasil penelitian yang telah dikerjakan oleh (Hasanuddin, 2018), dimana pada penelitiannya menghasilkan bukti empiris bahwa variabel komite audit terbukti memberikan pengaruh positif pada integritas LK. Akan tetapi hasil penelitian ini didukung oleh penelitian (Parinduri et al., 2019) yang menyatakan bahwa variabel komite audit tidak memiliki pengaruh pada integritas LK.

\section{Pengaruh Kualitas Audit Terhadap Integritas Laporan Keuangan}

Variabel kualitas audit berdasarkan hasil pengujian pada Tabel 6 mempunyai nilai koefisien sebesar 0,653. Nilai ini menunjukkan bahwa jika variabel kualitas audit berubah sebesar satu satuan dan variabel lain dianggap tetap, maka variabel integritas laporan keuangan akan bertambah sebesar 0,653 satuan. Pada Tabel 6 untuk variabel kualitas audit memiliki nilai probabilitas signifikansi hitung sebesar 0,001, nilai signifikansi ini lebih kecil dari tingkat kesalahan $\alpha$ yang diperbolehkan yaitu senilai 5\%. Sehingga dari hasil ini dapat dikatakan bahwa kualitas audit memiliki pengaruh positif serta pengaruhnya signifikan pada integritas LK. Temuan dari hasil penelitian ini sesuai dengan hipotesis ketiga pada awal mula diajukan yaitu kualitas audit memiliki pengaruh terhadap integritas LK. Kualitas audit memiliki pengaruh pada integritas laporan keuangan disebabkan karena auditor yang dipakai oleh perusahaan sudah memiliki spesialisasi untuk melakukan audit pada perusahaan yang bergerak di industri manufaktur. 
Hasil dari penelitian ini sependapat dengan hasil penelitian yang telah dikerjakan pada penelitian (Priharta, 2017) yang telah berhasil memberikan bukti secara empiris bahwa kualitas audit secara signifikan memiliki pengaruh positif pada integritas LK. Akan tetapi hasil yang telah diperoleh peneliti pada penelitian ini tidak sesuai dengan hasil penelitian yang telah dikerjakan oleh (Serly \& Helmayunita, 2019), dimana dari hasil penelitiannya tersebut yaitu terbukti secara empiris bahwa kualitas audit tidak mempunyai pengaruh pada integritas LK. Hasil penelitian ini memberikan implikasi bahwa kualitas audit atas laporan keuangan memberikan dampak terhadap peningkatan kepatuhan pada penerapan standar akuntansi keuangan yang disertai dengan peningkatan transparansi LK yang akan disajikan. Hal ini menjadikan kualitas audit juga termasuk salah satu faktor yang terbukti dapat mempengaruhi secara positif serta signifikan untuk meningkatkan nilai integritas LK.

\section{Pengaruh Pengungkapan CSR Terhadap Integritas Laporan Keuangan}

Hipotesis keempat penelitian ini yaitu pengungkapan corporate social responsibility memiliki pengaruh terhadap integritas LK. Dengan melihat pada hasil pengujian di Tabel 6, pengungkapan CSR mempunyai nilai koefisien sebesar 41,444 dan nilai signifikansi sebesar 0,000, nilai signifikansi ini tidak lebih besar dari 5\% sebagai tingkat kesalahan $\alpha$ yang diperbolehkan. Sehingga dapat dikatakan bahwa pengungkapan CSR memiliki pengaruh positif dan pengaruhnya signifikan pada integritas LK. Nilai koefisien yang dimiliki oleh variabel CSR berdasarkan perhitungan yaitu sebesar 41,444, ini berarti jika variabel pengungkapan CSR berubah sebesar satu satuan dan variabel lain dianggap tetap, maka variabel integritas laporan keuangan akan bertambah sebesar 41,444 satuan. Nilai koefisien untuk variabel CSR ini cukup besar jika dibandingkan dengan koefisien yang dimiliki oleh variabel yang lainnya. Hal menunjukkan tanda bahwa CSR memiliki pengaruh yang cukup besar terhadap variabel integritas LK dibandingkan dengan variabel kepemilikan institusi, komite audit, ukuran perusahaan, dan kualitas audit.

Pengungkapan CSR dapat mempengaruhi integritas LK disebabkan karena perusahaan melakukan kegiatan CSR dengan tujuan memberikan kontribusi pada masyarakat dan lingkungan yang diharapkan dapat bermanfaat untuk jangka panjang. Kegiatan CSR ini dilakukan untuk meminimalisasi dampak negatif dan meningkatkan dampak positif dari kegiatan operasi perusahaan terhadap semua pemangku kepentingan termasuk masyarakat untuk mencapai salah satu tujuan perusahaan yaitu berkelanjutan. Oleh sebab itu, dengan adanya pengungkapan kegiatan CSR pada laporan keuangan akan mendapatkan kepercayaan dari pemangku kepentingan dan LK akan dianggap wajar. Hasil penelitian ini turut memperkuat hasil penelitian yang telah dilakukan oleh (Cho et al., 2020), dimana penelitian tersebut memperoleh kesimpulan bahwa manajer perusahaan menggunakan pengungkapan CSR untuk menyampaikan informasi yang lebih kredibel ke pasar yang pada gilirannya dikaitkan dengan reaksi pasar yang kuat 
Analisis Penerapan Corporate Governance, Kualitas Audit dan Pengungkapan CSR Serta Ukuran Perusahaan Terhadap Integritas Laporan Keuangan

terhadap pengungkapan CSR. Hal ini menunjukkan bahwa CSR memberikan pengaruh positif pada peningkatan nilai integritas laporan keuangan.

\section{Pengaruh Ukuran Perusahaan Terhadap Integritas Laporan Keuangan}

Hipotesis kelima yang diajukan penelitian ini yaitu bahwa ukuran perusahaan memiliki pengaruh signifikan terhadap integritas LK. Hipotesis ini tidak terdukung dengan hasil pengolahan data sesuai dengan yang dipaparkan pada Tabel 6 . Hal ini dibuktikan dengan hasil pengujian untuk variabel ukuran perusahaan dari Tabel 6 yang memperoleh nilai probabilitas signifikansi hitung sebesar 0,649>0,05. Hasil perhitungan ini memberikan petunjuk bahwa variabel ukuran perusahaan terbukti tidak memiliki pengaruh signifikan pada integritas LK. Hasil yang diperoleh dari berdasarkan data yang dipaparkan Tabel 6 di atas tidak mendukung hipotesis yang diajukan oleh penelitian ini, karena hasil perhitungan menunjukkan komite audit memiliki koefisien yang bernilai negatif dan nilainya cukup kecil yaitu sebesar 0,022. Hal ini terjadi mungkin karena aset perusahaan tidak menjadi satu-satunya pertimbangan bagi investor untuk melakukan investasi pada perusahaan. Selain itu, total aset yang dimiliki oleh perusahaan mungkin belum secara maksimal digunakan oleh manajer, oleh karena itu tingkat integritas LK belum memiliki nilai yang baik.

Temuan dari penelitian ini tidak sependapat dengan hasil temuan oleh (Nurdiniah \& Pradika, 2017), dimana hasil penelitiannya tersebut menyimpulkan bahwa variabel ukuran perusahaan terbukti berpengaruh positif pada integritas laporan keuangan. Akan tetapi hasil penelitian ini mendukung temuan penelitian (Parinduri et al., 2019) dan (Wardhani \& Samrotun, 2020), sehingga dapat memperkuat kesimpulan bahwa ukuran perusahaan tidak berpengaruh terhadap integritas LK.

\section{Kesimpulan}

Berdasarkan bukti empiris hasil pengolahan data serta pembahasan yang sudah dilakukan bisa diperoleh kesimpulan bahwa kepemilikan instistusional, komite audit, kualitas audit, pengungkapan CSR dan ukuran perusahaan telah terbukti secara simultan berpengaruh signifikan terhadap variabel integritas LK. Namun secara parsial, hanya kepemilikan institusional, kualitas audit, dan pengungkapan CSR yang terbukti secara signifikan mempunyai pengaruh positif pada integritas LK. Sementara komite audit dan ukuran perusahaan terbukti tidak berpengaruh pada integritas LK.

Berdasarkan pada kesimpulan tersebut di atas, maka kemudian peneliti akan memberikan rekomendasi yang dapat digunakan untuk penelitian lebih lanjut. Untuk penelitian lebih lanjut bisa digunakan sampel perusahaan pada industri selain manufaktur dan periode penelitian yang lebih panjang daripada yang telah dilakukan saat ini yang hanya dilakukan untuk periode 3 tahun saja. Kemudian untuk penerapan tata kelola perusahaan dapat ditambahkan variabel lain seperti kepemilikan manajerial, komisaris independen dan dewan direksi agar dapat melihat secara lebih menyeluruh 
variable-variabel mana saja yang memang benar memiliki pengaruh terhadap integritas laporan keuangan.

\section{BIBLIOGRAFI}

Abdillah, Muhammad Rifqi, Mardijuwono, Agus Widodo, \& Habiburrochman, Habiburrochman. (2019). The effect of company characteristics and auditor characteristics to audit report lag. Asian Journal of Accounting Research, 4(1), 129-144. Google Scholar

Beaver, William H., \& Ryan, Stephen G. (2000). Biases and Lags in Book Value and Their Effects on the Ability of the Book-to-Market Ratio to Predict Book Return on Equity. Journal of Accounting Research, 38(1), 127. Google Scholar

Cho, Seong Yeon, Kang, Pyung Kyung, Lee, Cheol, \& Park, Cheong. (2020). Financial reporting conservatism and voluntary csr disclosure. Accounting Horizons, 34(2), 63-82. Google Scholar

Hasanuddin, Hasanuddin. (2018). the Influence of Good Corporate Governance, and Quality of Audit Against the Integrity of the Financial Statements Hasanuddin. International Journal of Economics Management and Social Science, 1(3), 111119. Google Scholar

Indrasari, Anita, Yuliandhari, Willy Sri, \& Triyanto, Dedik Nur. (2017). Pengaruh Komisaris Independen, Komite Audit, Dan Financial Distress Terhadap Integritas Laporan Keuangan. Jurnal Akuntansi, 20(1), 117. Google Scholar

Mais, Rimi Gusliana, \& Nuari, Fadlan. (2016). Pengaruh Good Corporate Governance, Ukuran Perusahaan, Dan Leverage Terhadap Integritas Laporan Keuangan. Jurnal Reviu Akuntansi Dan Keuangan, 6(2), 907-912. Google Scholar

Nurdiniah, Dade, \& Pradika, Endra. (2017). International Journal of Economics and Financial Issues Effect of Good Corporate Governance, KAP Reputation, Its Size and Leverage on Integrity of Financial Statements. International Journal of Economics and Financial Issues, 7(4), 174-181. Google Scholar

Parinduri, Aina Zahra, Pratiwi, Risma Koeshartanti, \& Purwaningtyas, Oktavina Ika. (2019). Analysis of Corporate Governance, Leverage and Company Size on the Integrity of Financial Statements. Indonesian Management and Accounting Research, 17(1), 18. Google Scholar

Priharta, Andry. (2017). Pengaruh Corporate Governance Terhadap Integritas Laporan Keuangan. JABE (Journal of Applied Business and Economics), 3(4), 234-250. Google Scholar

Santi, Desifa Kurnia, \& Wardani, Dewi Kusuma. (2018). Pengaruh Tax Planning, Ukuran Perusahaan, Corporate Social Responsibility (Csr) Terhadap Manajemen 
Analisis Penerapan Corporate Governance, Kualitas Audit dan Pengungkapan CSR Serta Ukuran Perusahaan Terhadap Integritas Laporan Keuangan

Laba. Jurnal Akuntansi, 6(1), 11-24. Google Scholar

Sauqi, Ahmad, Akram, \& Pituringsih, Endar. (2017). The Effect of Corporate Governance Mechanisms, Auditor Independence, and Audit Quality To Integrity of Financial Statements. International Conference and Call for Papers, 20. Retrieved from http://jurnal.stie-mandala.ac.id/index.php/eproceeding/article/view/191

Serly, Vanica, \& Helmayunita, Nayang. (2019). The Correlation of Audit Fee, Audit Quality and Integrity of Financial Statement. 64(2017), 67-72. Google Scholar

Setiawan, Liswan, \& Fitriany, Fitriany. (2011). Pengaruh Workload Dan Spesialisasi Auditor Terhadap Kualitas Audit Dengan Kualitas Komite Audit Sebagai Variabel Pemoderasi. Jurnal Akuntansi Dan Keuangan Indonesia, 8(1), 36-53. Google Scholar

Sultana, Nigar, Singh, Harjinder, \& Van der Zahn, J. L. W. Mitchel. (2015). Audit Committee Characteristics and Audit Report Lag. International Journal of Auditing, 19(2), 72-87.

Wardhani, Widya Kusuma, \& Samrotun, Yuli Chomsatu. (2020). Pengaruh Kepemilikan Institusional, Kepemilikan Manajerial, Ukuran Perusahaan dan Leverage terhadap Integritas Laporan Keuangan. Jurnal Ilmiah Universitas Batanghari Jambi, 20(2), 475. Google Scholar

Copyright holder:

Ranti Nugraheni (2021)

First publication right:

Syntax Idea

This article is licensed under: 